The INL is a

U.S. Department of Energy

National Laboratory

operated by

Battelle Energy Alliance

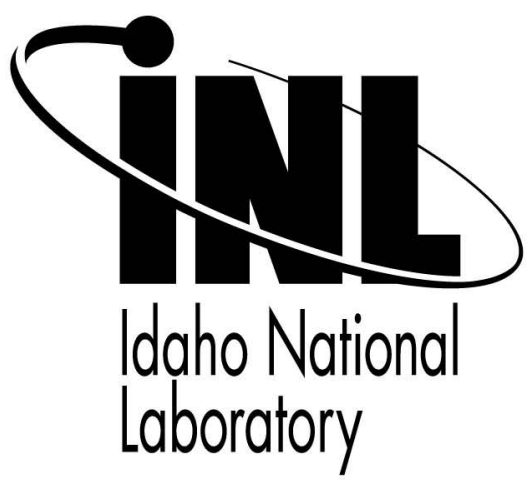

INL/CON-06-11869

PREPRINT

\section{Safeguards and Non- Proliferation Issues as} Related to Advanced Fuel Cycle and Advanced Fast Reactor Development with Processing of Reactor Fuel

\section{IEEE Nuclear Science Symposium, Medical Imaging Conference}

Rahmat Aryaeinejad Jerald D. Cole Mark W. Drigert Dee E. Vaden

\section{October 2006}

This is a preprint of a paper intended for publication in a journal or proceedings. Since changes may be made before publication, this preprint should not be cited or reproduced without permission of the author. This document was prepared as an account of work sponsored by an agency of the United States Government. Neither the United States Government nor any agency thereof, or any of their employees, makes any warranty, expressed or implied, or assumes any legal liability or responsibility for any third party's use, or the results of such use, of any information, apparatus, product or process disclosed in this report, or represents that its use by such third party would not infringe privately owned rights. The views expressed in this paper are not necessarily those of the United States Government or the sponsoring agency. 


\title{
Safeguards and Non-proliferation Issues as Related to Advanced Fuel Cycle and Advanced Fast Reactor Development with Processing of Reactor Fuel
}

\author{
Rahmat Aryaeinejad, Jerald D. Cole, Mark W. Drigert and Dee E. Vaden
}

\begin{abstract}
The goal of this work is to establish basic data and techniques to enable safeguards appropriate to a new generation of nuclear power systems that will be based on fast spectrum reactors and mixed actinide fuels containing significant quantities of "minor" actinides, possibly due to reprocessing, and determination of what new radiation signatures and parameters need to be considered. The research effort focuses on several problems associated with the use of fuel having significantly different actinide inventories that current practice and on the development of innovative techniques using new radiation signatures and other parameters useful for safeguards and monitoring. In addition, the development of new distinctive radiation signatures as an aid in controlling proliferation of nuclear materials has parallel applications to support Gen-IV and current advanced fuel cycle initiative (AFCI) goals as well as the anticipated Global Nuclear Energy Partnership (GNEP).
\end{abstract}

Index terms- Fuel Processing, Advanced fuel Cycle, Nonproliferation

\section{INTRODUCTION}

$\mathrm{T}^{\mathrm{h}}$ he safeguards regime must be applied to any processing of nuclear materials for either separation and transmutation (S\&T) performed as either part of a nuclear power program, processing and disposal of material as waste, or simply the control of special nuclear materials to prevent diversion or use in a nuclear weapons program. The traditional elements of safeguards with material accountancy and containment and surveillance are the key to safeguarding an S\&T operation, but these elements are generally specific to a given facility. The technical safeguards means are keyed to particular measurements or specific parameters that are identified as being important and sometimes critical to verify specific items, accountancy, or characteristics important to the verification of operational declarations. Radiation signatures that are used for such technical measurements are the interest of this work. There will be some discussion of current technical means used in safeguards operations as they will be applied to the new situations to be encountered in

Prepared for the U.S. Department of Energy through the Idaho National Laboratory LDRD program under DOE Idaho Operations Office, the Contract No. DE-AC07-99ID13727.

R. Aryaeinejad is with the Idaho National Lab., Idaho Falls, ID 834152114 USA (phone: 208-526-1670, e-mail: rahmat.aryaeinejad@inl.gov).

J.D. Cole is with the Idaho National Lab., Idaho Falls, ID 83415-2114 USA (phone: 208-526-4091, e-mail: Jerald.cole@inl.gov).

M.W. Drigert is with the Idaho National Lab., Idaho Falls, ID 83415-2114 USA (phone: 208-526-1057, e-mail: Mark.Drigert@inl.gov).

D.E. Vaden is with the Idaho National Lab., Idaho Falls, ID 83415-6180 USA (phone: 208-526-7609, e-mail: Dee.Vaden.@inl.gov). safeguarding nuclear materials processing efforts with regards to $\mathrm{S} \& \mathrm{~T}$.

Various processing systems will be discussed with regard to how radiation signatures are affected by the different methods. Particular attention will be given to PUREX, UREX, (in its several forms) and pyroprocessing as described under the Integral Fast Reactor (IFR) program of Argonne National Laboratory (ANL, Now part of the Idaho National Laboratory or INL). These systems will not be presented in detail except for the outputs of the processes. These systems have been presented in the literature and that detail will not be repeated here. The light water reactor (LWR) fuel will be used as the model for processing as there are well documented compositions of this spent fuel and the processed output. Some fairly generic composition will be used for evaluation of radiation signatures and existing safeguard measurement systems.

As examples of safeguards systems in current use, the IAEA techniques and equipment list will be used as these are operating systems and these systems will be discussed as general approaches, but not vendor specific equipment. This is not to exclude development of other systems as this is part of the reason to look for radiation signatures for processed material. This is done to restrict the discussion to more concrete situations and not launch into program of all new equipment. As stated the emphasis is on radiation signatures and as such are presented there will be some discussion of how such signatures can be measured and what information they would provide.

The current proposals to employ S\&T involve both processing and recycling of plutonium and other actinide materials in an actinide burner of some form. Exactly how this is to be done is critical to a safeguards effort that must be applied to this process. In all proposals that are either currently in use or being proposed, the presence of the actinides heavier than uranium become more important as the neptunium, americium, curium and californium isotopes play a major radiological role in safeguarding the plutonium to insure there is not diversion in some way to a weapons program or other undesirable uses of the material. The exact radiological signatures that can be used in safeguards verification and monitoring measurements are the subject of this study.

Little to no systematic research is supported in the area of new signatures as low-energy nuclear physics is not a current priority. Also, limited source of research quality actinide materials are available in U.S. and Few facilities are available 


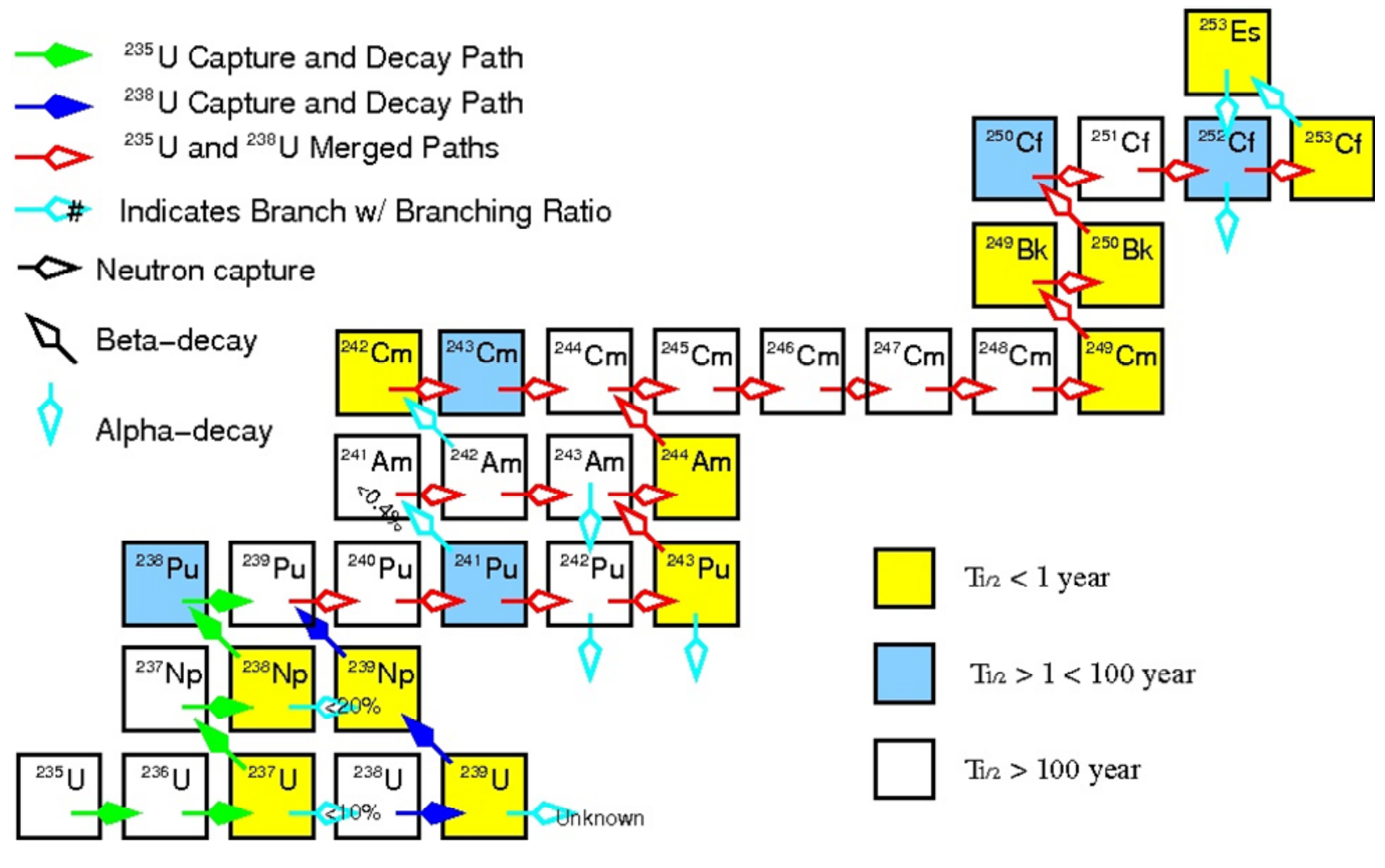

Figure 1. Actinides produced as a result of separation and transmutation processes.

for this work. In addition, there are discrepancies for some of the fission product yields in model calculations that need to be resolved by the experimental data.

\section{ACTINIDE ISOTOPES}

A key question is what are the plutonium and other materials that are to be considered as a product of the production and processing? This question is also affected by what processing system will be used, and the source of the spent fuel to be processed. For S\&T multiple pass processing and irradiation is assumed and this makes the determination of relative quantities and ratios of material difficult. A simple calculation of irradiation and burnup for a thermal neutron spectrum results in the isotopes seen in Figure 1[1]. These calculations used neutron fluxes from $10^{13} \mathrm{n} / \mathrm{cm}^{2} / \mathrm{s}$ to $10^{16} \mathrm{n} / \mathrm{cm}^{2} / \mathrm{s}$.

Figure 1 shows 33 isotopes including the uranium isotopes. Some references have as many as 51 isotopes [2] while others have as few as few as 20 [3]. For the case of processing, the short lived isotopes are not to be considered as they will decay significantly during cooling times and will not become important in the processing output. In general, the isotopes with a half-life greater than one year will be included for consideration as a safeguards issue. Also, the short lived isotopes are included as they are important in production of other isotopes during irradiation. For the cases of S\&T the decay of ${ }^{241} \mathrm{Pu}$ becomes important for the introduction of
${ }^{241} \mathrm{Am}$ and its products into the mix in significant quantities. The assumption is that these and some other actinide isotopes are to be the ones of concern for safeguards measurements with a cycle of multiple processing and irradiation. As to actual quantities of material produced there is substantial variation of both plutonium and other actinides in light water reactor (LWR) fuel due to initial enrichment, burnup, and data used in the analysis of spent fuel. The plutonium quantities vary from $0.6 \%$ to $0.2 \%$ of the units of heavy metal with the other actinides being from $1.0 \%$ to $1.5 \%$ of the plutonium mass [4].

Table in Appendix A lists the actinides and their relevant characteristics used in this work. The isotopes indicated by an "*" have too short a half live to be important in a separation system but they are important as a path for production of longer lived actinides during irradiation. The table list 20 actinides that have a half life greater than 10 years, ${ }^{249} \mathrm{Bk}$ is only nine years, and significant radiation signatures. These will be the basis of discussion. Appendix A also gives the $\alpha-$ and $\beta$-particle decay chains these actinides will be discussed a signatures for identifying and quantifying these actinides in the processed output.

\section{FUEL Processing Systems}

Processing of spent nuclear fuel is currently being done in France and the United Kingdom using the PUREX [5] process. This is a well established process and safeguards 
procedures, as applied to PUREX and its installations, are well understood and have been developed to a very high degree. A key point to the output of the PUREX system is that the materials that are to be safeguarded, the plutonium, is very pure and free from contaminates from other actinides. For radiological measurements to verify the plutonium, this makes the task somewhat simpler than for a mixed processing output. The safeguard measures for a PUREX process will not be discussed here.

New processing systems are being researched and developed under the AFCI program [6] with the goal of reducing the cost and complexity of processing and tailoring the output streams to facilitate the problems concerned with the nuclear waste and the geological repository. These fall into the categories of aqueous and non-aqueous systems. The aqueous systems are generally based on the UREX and PUREX processes with simplification and cost reduction with the output streams tailored to specific needs of storage and transmutation. The aqueous process that will be discussed here is $\mathrm{UREX}+[7,8]$ and its variations.

For non-aqueous processing the focus of this work will be on pyroprocessing $[9,10]$ as developed by ANL in the IFR program. Pyroprocessing is not a continuous process but operates on batches of fuel in an electrochemical cell that is a $\mathrm{LiCl}$ bath operated at $650^{\circ} \mathrm{C}$. Oxygen is liberated in the process and the reduced metals are collected in the cathode basket. This basket becomes the anode in the next step, where uranium is extracted by an electrorefining process. The metallic uranium is deposited on a cathode, and the uranium is recovered by melting at reduced pressure to volatilize off any adhering $\mathrm{LiCl}$. The transuranic elements, and all but the noble metal fission products, are dissolved in the electrorefining process and remain in the $\mathrm{LiCl}$ electrolyte salt. The transuranics (and a quantity of the remaining uranium) can be recovered in a liquid cadmium cathode, collecting about 3-5 $\mathrm{kg}$ of TRU elements per batch. Alternatively, an electrowinning process could be used to extract the transuranics after the electrorefining step to recover uranium. There are other details and variations of this process but they will not be covered here the focus is on what are the output and the uncertainties in mass of the different outputs that are important to safeguards.

\section{a) UREX+ Process}

At this time the AFCI program is proposing the UREX+ processing in several variations for SNF. Table I lists the UREX+ process and identifies the different outputs from each variant. The reason for the different forms of UREX + is determined by the different uses of the output streams and how they are to be handled for disposal. The removal of the uranium, technetium and iodine, cesium and strontium, and transuranics is an effort to maximize space in the geological repository and reduce heat loading in the repository. The uranium in SNF comprises about $96-97 \%$ of the mass of the fuel. UREX+ process has the goal, and laboratory scale demonstrations have shown, $[9,10]$ that uranium recovery is $>90 \%$, and its purity requirement will allow its waste disposal as low-level waste according to 10CFR61.55. This is the criterion that the uranium contain less than $100 \mathrm{nCi} / \mathrm{g}$ of TRU. Separation of technetium and iodine allows transmutation of these two long lived isotopes and have the requirement that separation must be $>95 \%$ with the technetium containing less than $16 \mu \mathrm{g}$ of fissile actinides per $\mathrm{g}$ and the iodine output must contain less than $4 \mu \mathrm{g}$ of fissile actinides per g. Cesium and strontium are recovered at better than $97 \%$ and the purity requirement of $100 \mathrm{nCi} / \mathrm{g}$ of $\mathrm{TRU}$ content allows ultimate disposal as low-level waste at a later time. Plutonium and neptunium recovery is $>99 \%$, and the purity is such that the mixed-oxide (MOX) fuel specifications is met as described in ASTM C833-01. The recovery of americium and curium is $99.5 \%$ and the purity, and, based on fast-reactor recycle of all TRU, has a lanthanide content $<20 \mathrm{mg} / \mathrm{g}$ uranium plus TRU. All soluble fission products but $\mathrm{Cs}, \mathrm{Sr}, \mathrm{Tc}, \mathrm{I}$, and the rare earth elements are converted to a solid for disposal in the repository. As stated this has been demonstrated on SNF at a laboratory scale.

The simple picture of safeguards radiation signatures and measurements needed for UREX + processing looks straight

\begin{tabular}{|c|c|c|c|c|c|c|c|}
\hline \multicolumn{7}{|c|}{ Table I. A summary of the UREX+ processes characterized by the different outputs. } \\
\hline \multirow{2}{*}{ Process } & 1 & 2 & 3 & 4 & 5 & 6 & 7 \\
\cline { 2 - 9 } & $\mathrm{U}$ & $\mathrm{Tc}-\mathrm{I}$ & $\mathrm{Cs}-\mathrm{Sr}$ & $\mathrm{TRU}-\mathrm{Tn}$ & $\begin{array}{c}\text { Fission } \\
\text { Products }\end{array}$ & & \\
\hline UREX+1 & $\mathrm{U}$ & $\mathrm{Tc}-\mathrm{I}$ & $\mathrm{Cs}-\mathrm{Sr}$ & $\mathrm{TRU}$ & $\begin{array}{c}\text { All Fission } \\
\text { Products }\end{array}$ & \\
\hline UREX+2 & $\mathrm{U}$ & $\mathrm{Tc}-\mathrm{I}$ & $\mathrm{Cs}-\mathrm{Sr}$ & $\mathrm{Pu}-\mathrm{Np}$ & Am-Cm-Ln & $\begin{array}{c}\text { Fission } \\
\text { Products }\end{array}$ & \\
\hline UREX+3 & $\mathrm{U}$ & $\mathrm{Tc}-\mathrm{I}$ & $\mathrm{Cs}-\mathrm{Sr}$ & $\mathrm{Pu}-\mathrm{Np}$ & Am-Cm & $\begin{array}{c}\text { All Fission } \\
\text { Products }\end{array}$ & \\
\hline UREX+4 & $\mathrm{U}$ & Tc-I & Cs-Sr & Pu-Np & Am & Cm & $\begin{array}{c}\text { All Fission } \\
\text { Products }\end{array}$ \\
\hline
\end{tabular}


forward but there are some issues that must be covered along with the differences between the situations with PUREX processing. Both processes produce well separated outputs but the key difference between UREX+ and PUREX is the additional separation of key fission products, the purity of the uranium output and the plutonium and other actinides (TRU) in a mixed form. The UREX+ process is predicted to be more economical than the PUREX with less waste but those are not of interest here. The PUREX process produces separated plutonium for use in MOX fuel and the primary issue from a safeguards approach is the amount of plutonium and the isotopic ratio of the ${ }^{239} \mathrm{Pu} /{ }^{240} \mathrm{Pu}$ isotopes [11]. The PUREX plutonium output is of sufficient purity to be used in MOX fuel but it is not mixed with other actinides. For UREX+1a, the presence of other actinides poses serious problems using gross radiation measurements, for both neutron and gamma ray. For situations where mass spectroscopy can be used these mixtures should not be a problem but for radiation verification measurements even using high resolution gammaray spectroscopy, these mixtures present a challenge to a standard approach.

For the UREX $+2,3$, and 4 processes, some of the same problems exist for the plutonium/neptunium output as the simple plutonium isotopic ratio measurements are complicated by the presence of the neptunium. Using low-energy $\mathrm{x}$-ray analysis becomes more difficult due to the presence of elements separated by only one $Z$ following $\alpha$-particle decay. With presence of ${ }^{241} \mathrm{Pu}$ in SNF with long cooling times, the ${ }^{241} \mathrm{Am}$ presence further complicates this elemental measurement. For the case of high burnup fuel, even with the separation of the plutonium/neptunium output with $>99 \%$ efficiency from the other actinides, this present significant problems due to the high specific activity of the other actinides as compared to the plutonium and neptunium (See Appendix A). In some cases the specific activity for the americium and curium isotopes are more than two orders of magnitude higher than that of the ${ }^{239} \mathrm{Pu}$ making the $1 \%$ or so contamination be the dominate component on a radiological measurement. Even with the differences in mass in the fractions that are present in the spent fuel, this small contamination can be problematic. The ratios of the isotopes will be discussed later but with recycling through either LWRs or fast reactors for the TRU and plutonium, the mass ratios become more disadvantageous.

\section{a) Pyroprocessing}

Although there are several non-aqueous spent fuel processing systems, the one to be considered her is the pyroprocessing method developed by ANL for the IFR program. For the pyroprocessing an electrorefiner process

Table II. Pyroprocessing of different types of reactor fuels (model calculations).

\begin{tabular}{|c|c|c|c|c|c|c|}
\hline \multirow{2}{*}{$\begin{array}{c}\text { Composition } \\
\text { Source }\end{array}$} & \multicolumn{3}{|c|}{ At Reactor Discharge (g / kg spent fuel) } & \multicolumn{3}{|c|}{ After Pyroprocessing (g / Kg Metal) } \\
\hline & IFR & BWR & JPDR & IFR & BWR & JPDR \\
\hline GWd/MTU & & 18.96 & 2.71 & & 18.96 & 2.71 \\
\hline U234 & $3.17 \mathrm{E}-02$ & $1.96 \mathrm{E}-01$ & $1.47 \mathrm{E}-01$ & $1.25 \mathrm{E}-02$ & $7.46 \mathrm{E}-02$ & $6.04 \mathrm{E}-02$ \\
\hline $\mathrm{U} 235$ & $9.33 \mathrm{E}-01$ & $1.38 \mathrm{E}+01$ & $2.30 \mathrm{E}+01$ & $5.78 \mathrm{E}-01$ & $5.23 \mathrm{E}+00$ & $9.44 \mathrm{E}+00$ \\
\hline $\mathrm{U} 236$ & $1.71 \mathrm{E}-01$ & $3.04 \mathrm{E}+00$ & $6.92 \mathrm{E}-01$ & $6.76 \mathrm{E}-02$ & $1.15 \mathrm{E}+00$ & $2.84 \mathrm{E}-01$ \\
\hline $\mathrm{U} 238$ & $7.75 E+02$ & $9.75 \mathrm{E}+02$ & $9.74 \mathrm{E}+02$ & $3.88 \mathrm{E}+02$ & $3.73 \mathrm{E}+02$ & $4.00 \mathrm{E}+02$ \\
\hline U237 & $2.33 \mathrm{E}-07$ & & & $9.20 \mathrm{E}-08$ & & \\
\hline $\mathrm{Pu} 238$ & $1.40 \mathrm{E}+00$ & & $3.02 \mathrm{E}-04$ & $3.85 \mathrm{E}+00$ & & $1.33 \mathrm{E}-01$ \\
\hline Pu239 & $1.67 \mathrm{E}+02$ & $4.32 \mathrm{E}+00$ & $1.23 \mathrm{E}+00$ & $4.60 \mathrm{E}+02$ & $4.21 \mathrm{E}+02$ & $5.44 \mathrm{E}+02$ \\
\hline $\mathrm{Pu} 240$ & 4.47E+01 & $1.41 \mathrm{E}+00$ & 7.64E-02 & $1.23 \mathrm{E}+02$ & $1.37 \mathrm{E}+02$ & $3.37 \mathrm{E}+01$ \\
\hline Pu241 & $4.77 \mathrm{E}+00$ & $3.93 \mathrm{E}-01$ & $8.50 \mathrm{E}-03$ & $1.31 \mathrm{E}+01$ & $3.83 \mathrm{E}+01$ & $3.75 \mathrm{E}+00$ \\
\hline $\mathrm{Pu} 242$ & $1.90 \mathrm{E}+00$ & $1.14 \mathrm{E}-03$ & $1.93 \mathrm{E}-04$ & $5.23 \mathrm{E}+00$ & $1.11 \mathrm{E}-01$ & $8.54 \mathrm{E}-02$ \\
\hline $\mathrm{Pu} 236$ & $1.37 \mathrm{E}-05$ & & & $3.77 \mathrm{E}-05$ & & \\
\hline Np237 & $1.38 \mathrm{E}+00$ & $1.82 \mathrm{E}-01$ & & $3.42 \mathrm{E}+00$ & $1.60 \mathrm{E}+01$ & \\
\hline Am241 & $1.55 \mathrm{E}+00$ & $1.75 \mathrm{E}-01$ & $1.82 \mathrm{E}-03$ & $2.85 \mathrm{E}+00$ & $1.14 \mathrm{E}+01$ & $5.39 \mathrm{E}-01$ \\
\hline $\mathrm{Am} 242 \mathrm{~m}$ & $1.14 \mathrm{E}-01$ & & & $2.10 \mathrm{E}-01$ & & \\
\hline $\mathrm{Cm} 242$ & $7.96 \mathrm{E}-02$ & & $1.13 \mathrm{E}-07$ & $1.18 \mathrm{E}-01$ & & $2.71 \mathrm{E}-05$ \\
\hline $\mathrm{Cm} 244$ & $1.78 \mathrm{E}-01$ & $1.55 \mathrm{E}-03$ & 5.82E-08 & $2.64 \mathrm{E}-01$ & $8.14 \mathrm{E}-02$ & $1.39 \mathrm{E}-05$ \\
\hline Am243 & $3.89 \mathrm{E}-01$ & & & $7.16 \mathrm{E}-01$ & & \\
\hline $\mathrm{Cm} 243$ & $4.32 \mathrm{E}-03$ & $3.76 \mathrm{E}-05$ & & $6.40 \mathrm{E}-03$ & $1.98 \mathrm{E}-03$ & \\
\hline $\mathrm{Cm} 245$ & $3.65 \mathrm{E}-02$ & & & $5.41 \mathrm{E}-02$ & & \\
\hline $\mathrm{Cm} 246$ & $1.06 \mathrm{E}-02$ & & & $1.57 \mathrm{E}-02$ & & \\
\hline
\end{tabular}


model [12] has been used to estimate the composition of the pyroprocessing product for IFR spent fuel. For efficient TRU extraction in the pyroprocessing, the electrorefiner requires a ratio of plutonium to uranium $(\mathrm{Pu}: \mathrm{U})$ above three. For this processing we used an electrorefiner process model to estimate the composition of the pyroprocessing product for IFR spent fuel as well as several thermal reactor types spent fuel with different burn up. Table II shows the results of some of the the estimated product composition for IFR, BWR, and JPDR fuels. As shown in Table II, Uranium recovery from processing $96 \mathrm{~kg}$ of IFR spent fuel with the composition [3], will achieve a $\mathrm{Pu} / \mathrm{U}$ ratio in the electrorefiner of 3.35 . Using a liquid cadmium cathode for TRU extraction, the estimated product composition for IFR spent fuel is shown in this Table.

Unlike the UREX+ or PUREX process, pyroprocessing has considerable uncertainties in both the separation of each output and the total amount of material processed because some material is held in the salt bath until the salt is recovered after several batches have been processed. The uncertainty in the estimation, per element, is shown in Table III. These high uncertainties indicate that a better method like radiation signatures is needed to achieve less than 5\% accuracy. Also, using the radiation signatures enable us to measure uncertainty for each individual isotope.

Mass spectroscopy can establish purities of the different material with very high accuracy but radiological analysis will require high resolution gamma-ray spectroscopy with different

Table III. Calculated pyroprocessing errors. The model does not calculate the uncertainty for each isotopes.

\begin{tabular}{|c|c|}
\hline Element & \%Error \\
\hline $\mathrm{Np}$ & $27 \%$ \\
\hline $\mathrm{Pu}$ & $6 \%$ \\
\hline $\mathrm{Am}$ & $39 \%$ \\
\hline $\mathrm{Cm}$ & $12 \%$ \\
\hline $\mathrm{U}$ & $13 \%$ \\
\hline
\end{tabular}

data reduction from the conventional methods used for current MOX fuels. Tables II also present the situation that exists for the IFR case on both the fuel at discharge and after processing. Unlike the LWR spent fuel composition that can be found from direct analysis of spent nuclear fuel over the past decades, [13] there are few cases of spent fuel analysis for fast reactors. Table II will be relevant for discussion of radiological measurements for safeguarding processed fast reactor fuel. For the situation in which fuel is processed and then recycled in a fast reactor as an actinide burner, this is the only information on post irradiation composition except for complex models of the reactor cores that are being developed.
The IFR case has the advantage of being benchmarked against some destructive analysis.

\section{CONCLUSIONS}

Both policy and well as technical decisions will determine the processing methods used and the composition of the different outputs of the different methods. Regarding radiological signatures, possible addition of highly radioactive isotopes like the lanthanides with the outputs of the UREX +1 or UREX+2 processes greatly complicate verification measurements used in safeguards. The presence of the lanthanides also raises problems for the use of the actinide materials as fuel in either fast reactors or in LWRs as actinide burners. The mixing of actinides into one output stream, or even two, create measurement problems due to the broad range of specific activities of the different actinide isotopes. This particularly affects gross radiation measurements on a finished fuel form. The amount of material to be measured at one time greatly affects the ability to measure radiological signatures. In the case where samples can be taken, as during a processing step, the problems of high activity can be mitigated by a small sample size but overall sensitivity to mixed materials may not be helped. Obviously mass spectrometry in several forms will be used in a processing facility, but radiological measurements will be needed particularly when samples cannot be taken or there is movement of finished material between material balance areas. With multiple processing plans and different output possibilities, no one radiological signature or technique will probably suffice. Several cases with explicit conditions of the process outputs will need to be considered.

Future work involves (a) Identify the basic parameters of the measurements that are needed; (b) Determine the exact effect of the contributions of different uncertainties; (c) Comparing the expected performance with the results of actual measurements of well-known amount of materials as well as with the model calculations; and (d) If possible, other fission isotopes gamma-ray ratios should be used to confirm the results.

\section{REFERENCES}

[1] Program Nuclides.net by Joseph Magill, European Commission Joint Research Centre, Institute for Transuranic Elements, Karlsruhe, Germany, www.nuclides.net.

[2] National Research Council, Nuclear Waste: Technologies for Separation and Transmutation, (National Academy Press, Washington, D.C., 1995), p. 22.

[3] W.H. Hannum, D.C. Wade, H.F. McFarlane, and R.N. Hill, NonProliferation and Safeguards Aspects of the IFR, Prog. Nucl. Energy, 31, 203 (1997).

[4] I.C. Gauld and C.V. Parks, Review of Technical Issues Related to Predicting Isotopic Compositions and Source Terms for High-Burnup LWR Fuel, NUREG/CR-6701 (2001).

[5] PUREX stands for plutonium-uranium reduction and extraction. A description can be found in appendix d of National Research Council, Nuclear Waste: Technologies for Separation and Transmutation, (National Academy Press, Washington, D.C., 1995), p. 147. 
[6] J. J. Laidler and J. C. Bresee, "The Advanced Fuel Cycle Initiative of the U.S. Department of Energy: Development of Separations Technologies," Proceedings of WM-04, Tucson, AZ February-March, 2004

[7] George F. Vandegrift, et al., Designing and Demonstration of the UREX+ Process Using Spent Nuclear Fuel, Proceeding of the Advances for Future Nuclear Fuel Cycles International Conference, Nimes, France, (2004).

[8] C. Pereia, et al., Lab-Scale Demonstration of the UREX+2 Process Using Spent Fuel, WM'05 Conference, Tucson, Arizona, (2005).

[9] J.J. Laidler, et al., Development of Pyroprocessing Technology, Prog. Nucl. Energy, 31, 131 (1997).
[10] C.C. McPheeters, R.D. Pierce, T.P. Mulcahey, Application of the pyrochemical process to recycle of actinides from LWR spent fuel, Prog. Nucl. Energy, 31, 175 (1997).

[11] H. Aigner, et al., International Target Values 2000 for Measurement Uncertainties in Safeguarding Nuclear Materials, IAEA/STR-327 (2001).

[12] D. Vaden, "Fuel Conditioning Facility Electrorefiner Process Model", Separation Science and Technology, Volume 41, special issue 10/11, to be published.

[13] Mochizuki,H., Suyama,K., Nomura,Y., and Okuno, H., "Spent Fuel Composition Database System on WWW - SFCOMPO on WWW Ver.2," JAERI-Data/Code 2001-020, Japan Atomic Energy Research Institute (August 2001); and www.nea.fr/html/science/wpncs/sfcompo.

\begin{tabular}{|c|c|c|c|c|c|c|c|}
\hline Isotope & $\alpha \mathbf{T}_{1 / 2}$ & $\begin{array}{c}v \text { bar } \\
\text { prompt }+ \\
\text { delayed }\end{array}$ & $\begin{array}{c}\text { Specific } \\
\text { Activity } \\
\text { Ci/g }\end{array}$ & $\begin{array}{c}\beta \text { Branch } \\
\beta-\text { unless noted }\end{array}$ & $\alpha$ Branch & $\begin{array}{c}\text { SF } \\
\text { Branch }\end{array}$ & $\begin{array}{l}\text { Specific Neutron } \\
\text { Activity } n / g / s\end{array}$ \\
\hline Np237 & $2140000 \mathrm{y}$ & 2.63581 & $7.03 \mathrm{E}-04$ & & 1.00 & & \\
\hline Np238* & $2.117 \mathrm{~d}$ & 2.79000 & $2.59 \mathrm{E}+05$ & 1.00 & & & \\
\hline Np239* & $2.355 \mathrm{~d}$ & 2.66180 & $2.32 \mathrm{E}+05$ & 1.00 & & & \\
\hline Pu238 & $87.69992 \mathrm{y}$ & 2.89471 & $1.71 \mathrm{E}+01$ & & 1.00 & $1.86 \mathrm{E}-09$ & $3.414 \mathrm{E}+03$ \\
\hline Pu239 & $24113.5 \mathrm{y}$ & 2.87777 & $6.22 \mathrm{E}-02$ & & 0.9994 & $3.10 \mathrm{E}-12$ & $2.052 \mathrm{E}-02$ \\
\hline Pu240 & $6536 \mathrm{y}$ & 2.78391 & $2.27 \mathrm{E}-01$ & & 1.00 & $5.70 \mathrm{E}-08$ & $1.331 \mathrm{E}+03$ \\
\hline $\mathrm{Pu} 241$ & $14.33029 \mathrm{y}$ & 2.93130 & $1.03 \mathrm{E}+02$ & 0.999975 & $2.46 \mathrm{E}-05$ & & \\
\hline Pu242 & $373509 y$ & 2.85950 & $3.95 \mathrm{E}-03$ & & 1.00 & $5.50 \mathrm{E}-06$ & $2.296 \mathrm{E}+03$ \\
\hline Pu243* & $4.956 \mathrm{~h}$ & 3.01000 & $2.60 \mathrm{E}+06$ & 1.00 & & & \\
\hline Pu244 & $80001800 \mathrm{y}$ & 2.82000 & $1.81 \mathrm{E}-05$ & & 0.99875 & $1.25 \mathrm{E}-03$ & $2.365 \mathrm{E}+03$ \\
\hline Am241 & $432.80832 \mathrm{y}$ & 3.23879 & $3.43 \mathrm{E}+00$ & & 1.00 & $4.30 \mathrm{E}-12$ & $1.769 \mathrm{E}+00$ \\
\hline Am242* & $16.04 \mathrm{~h}$ & 3.36000 & $8.08 \mathrm{E}+05$ & 0.832 & 0.168 & & \\
\hline $\mathrm{Am} 242 \mathrm{~m}$ & $141.00296 \mathrm{y}$ & 3.26400 & $1.05 \mathrm{E}+01$ & 0.99537 to GS & 0.00463 & $1.60 \mathrm{E}-10$ & $2.026 \mathrm{E}+02$ \\
\hline Am243 & $7370.01 \mathrm{y}$ & 3.27283 & 1.99E-01 & & 1.00 & $3.70 \mathrm{E}-11$ & $8.937 \mathrm{E}-01$ \\
\hline Am244* & $10.1 \mathrm{~h}$ & 3.15180 & $1.27 \mathrm{E}+06$ & 1.00 & & & \\
\hline $\operatorname{Am} 244 m^{*}$ & $26 \mathrm{~min}$ & 3.15180 & $2.97 \mathrm{E}+07$ & $\begin{array}{c}\beta+0.000361 \\
\beta-0.999639\end{array}$ & & & \\
\hline $\mathrm{Cm} 242^{*}$ & $162.93056 \mathrm{~d}$ & 3.44000 & $3.32 \mathrm{E}+03$ & & 1.00 & $6.10 \mathrm{E}-08$ & $2.581 \mathrm{E}+07$ \\
\hline $\mathrm{Cm} 243$ & $28.5 \mathrm{y}$ & 3.43201 & $5.05 \mathrm{E}+01$ & 0.0024 & 0.9976 & & \\
\hline $\mathrm{Cm} 244$ & $18.00039 \mathrm{y}$ & 3.46000 & $8.08 \mathrm{E}+01$ & & 0.99999 & $1.38 \mathrm{E}-06$ & $1.428 \mathrm{E}+07$ \\
\hline $\mathrm{Cm} 245$ & $8500.19 \mathrm{y}$ & 3.59640 & $1.72 \mathrm{E}-01$ & & 1.00 & & \\
\hline $\mathrm{Cm} 246$ & $4730.09 \mathrm{y}$ & 3.61416 & $3.08 \mathrm{E}-01$ & & 0.99973 & $2.61 \mathrm{E}-04$ & $1.077 \mathrm{E}+07$ \\
\hline $\mathrm{Cm} 247$ & $16000400 y$ & 3.58000 & $9.51 \mathrm{E}-05$ & & 1.00 & & \\
\hline $\mathrm{Cm} 248$ & $340008 \mathrm{y}$ & 3.12960 & $4.24 \mathrm{E}-03$ & & 0.9174 & 0.0826 & $4.059 \mathrm{E}+07$ \\
\hline Cm249* & $1.06917 \mathrm{~h}$ & 3.34880 & $1.18 \mathrm{E}+07$ & 1.00 & & & \\
\hline Bk247 & $1360 \mathrm{y}$ & 3.50670 & $1.05 \mathrm{E}+00$ & & 1.00 & & \\
\hline Bk248 & $9.00018 \mathrm{y}$ & & $1.60 \mathrm{E}+02$ & & & & \\
\hline Bk248m* & $23.7 \mathrm{hr}$ & & $5.32 \mathrm{E}+05$ & $\beta+0.3 ; \beta-0.7$ & & & \\
\hline Bk249* & $320 \mathrm{~d}$ & 3.34640 & $1.64 \mathrm{E}+03$ & 0.999986 & $1.45 \mathrm{E}-05$ & $4.69 \mathrm{E}-10$ & $9.511 \mathrm{E}+04$ \\
\hline Bk250* & $3.217 \mathrm{~h}$ & 3.57200 & $3.89 \mathrm{E}+06$ & 1.00 & & & \\
\hline Cf248* & $333.5 \mathrm{~d}$ & & $1.58 \mathrm{E}+03$ & & 1.00 & & \\
\hline Cf249 & $351.00694 \mathrm{y}$ & 3.88690 & $4.08 \mathrm{E}+00$ & & 1.00 & $5.20 \mathrm{E}-09$ & $3.052 \mathrm{E}+03$ \\
\hline Cf250 & $13.08027 \mathrm{y}$ & 3.63000 & $1.09 \mathrm{E}+02$ & & 0.99923 & 7.70E-04 & $1.129 \mathrm{E}+10$ \\
\hline Cf251 & $898.01839 \mathrm{y}$ & 4.14000 & $1.58 \mathrm{E}+00$ & & 1.00 & & \\
\hline Cf252 & $2.64505 \mathrm{y}$ & 4.06000 & $5.35 \mathrm{E}+02$ & & 0.96908 & $3.09 \mathrm{E}-02$ & $2.486 \mathrm{E}+12$ \\
\hline Cf253* & $17.81 \mathrm{~d}$ & 4.15000 & $2.89 \mathrm{E}+04$ & 0.9969 & 0.00310 & & \\
\hline Es253* & $20.47 \mathrm{~d}$ & & $2.52 \mathrm{E}+04$ & & 1.00 & $8.70 \mathrm{E}-08$ & \\
\hline
\end{tabular}

